\title{
ANALISIS SWOT IMPLEMENTASI TEKNOLOGI FINANSIAL TERHADAP KUALITAS LAYANAN PERBANKAN DI INDONESIA
}

\author{
Imanuel Adhitya Wulanata Chrismastianto \\ Fakultas Ilmu Pendidikan, Universitas Pelita Harapan Tangerang \\ imanuel.wulanata@uph.edu
}

\begin{abstract}
It is widely expected that Indonesian banking firms significantly improve their services to reach wider market segments, especially those residing in the $3 T$ areas (terdepan, terluar, and terpencil or the outermost and most remote). However, in reality Indonesian banks only develop minimum outreach to societies in the $3 T$ areas. Considering this issue, we develop and implement the SWOT analysis of financial technology policy in order to improve Indonesian banking services, especially in expanding their services to broader Indonesian societies. Also it is expected that banking industry's stakeholders understand better the role of good banking management based on the fear of God and respecting others in managing their internal and external assets that encompass holistic banking activities. Therefore, this study aims to further analyze the influence of strength, weakness, opportunities, and threats (SWOT) of financial technology implementation on Indonesian banking service quality in the digital era through the study of banking literature.
\end{abstract}

Keywords: financial technology, banking services, service quality.

\begin{abstract}
ABSTRAK
Menyikapi realisasi era digital saat ini, kualitas layanan perbankan di Indonesia diharapkan semakin meningkat secara signifikan, agar mampu menjangkau seluruh lapisan masyarakat, khususnya bagi masyarakat yang tinggal di daerah 3T (Terdepan, Terluar, dan Terpencil). Namun, pada kenyataannya kualitas layanan perbankan di Indonesia saat ini masih minim dalam mengakses masyarakat yang tinggal di daerah $3 \mathrm{~T}$ tersebut. Mencermati berbagai realita yang telah diuraikan di atas, maka melalui analisis SWOT implementasi kebijakan teknologi finansial ini, diharapkan kualitas layanan perbankan semakin dapat ditingkatkan dan dirasakan oleh seluruh lapisan masyarakat Indonesia secara riil dan para pelaku perbankan dapat memahami pengelolaan fungsi manajemen perbankan dengan tepat didasarkan pada sikap takut akan Tuhan dan menghargai sesama, dalam konteks pengelolaan aset internal maupun eksternal yang mencakup aktivitas perbankan secara holistik. Dengan demikian, tulisan ini bertujuan untuk menganalisis secara lebih mendalam mengenai kekuatan, kelemahan, peluang, dan ancaman (SWOT) implementasi teknologi finansial terhadap kualitas layanan perbankan Indonesia di era digital melalui studi literatur perbankan.
\end{abstract}

Kata Kunci: teknologi finansial, layanan perbankan, kualitas layanan. 


\section{PENDAHULUAN}

Perkembangan ilmu pengetahuan dan teknologi yang semakin pesat di era digital saat ini telah memengaruhi pola perilaku manusia dalam mengakses beragam informasi dan berbagai fitur layanan elektronik. Salah satu perkembangan teknologi yang menjadi bahan kajian terkini di Indonesia adalah Teknologi Finansial atau Financial Technology (FinTech) dalam lembaga perbankan. Menurut definisi yang dijabarkan oleh National Digital Research Centre (NDRC), teknologi finansial adalah istilah yang digunakan untuk menyebut suatu inovasi di bidang jasa finansial, di mana istilah tersebut berasal dari kata "financial" dan "technology" (FinTech) yang mengacu pada inovasi finansial dengan sentuhan teknologi modern (Sukma 2016). Konsep FinTech tersebut mengadaptasi perkembangan teknologi yang dipadukan dengan bidang finansial pada lembaga perbankan, sehingga diharapkan bisa memfasilitasi proses transaksi keuangan yang lebih praktis, aman serta modern, meliputi layanan keuangan berbasis digital yang saat ini telah berkembang di Indonesia, yaitu payment channel system, digital banking, online digital insurance, Peer to Peer (P2P) Lending, serta crowd funding (Siregar 2016). Konsep di atas senada dengan apa yang disampaikan oleh Deputi Direktur Direktorat Perizinan dan Informasi Perbankan OJK, Tris Yulianta, mengungkapkan bahwa lembaga perbankan perlu memanfaatkan penerapan teknologi finansial untuk meningkatkan efisiensi kegiatan operasional dan mutu pelayanan bank kepada nasabahnya, sebab pemanfaatan teknologi finansial tersebut sejalan dengan semakin berkembangnya kebutuhan masyarakat akan layanan keuangan berbasis online dan penggunaan media internet untuk akses data digital (Apriyani 2016). Hal ini berarti dengan adanya kemajuan teknologi perbankan tersebut, maka efektivitas waktu dapat dipercepat dalam sistem transaksi perbankan antar nasabah (Firmansyah dan Widiati 2016). Pernyataan tersebut juga didukung oleh hasil survei yang dipublikasikan oleh Asosiasi Penyedia Jasa Internet Indonesia (APJII) pada bulan Maret 2015, yang menyatakan bahwa jumlah pengguna internet di Indonesia naik dari 71,9 juta di 2013 menjadi 88,1 juta pengguna hingga akhir 2014, atau sekitar 34,9 persen dari total jumlah penduduk saat ini (Heriyanto 2015). Hal ini menunjukkan bahwa dalam hal jumlah, penetrasi pemanfaatan teknologi digital di Indonesia sangat besar, bahkan melebihi populasi gabungan negara-negara lain di ASEAN, dan telah mengubah perilaku masyarakat hampir pada semua aspek kehidupan, seperti jual beli secara online (e-commerce), interaksi sosial secara digital, buku elektronik, koran elektronik, transportasi publik (taksi dan ojek), layanan pendukung pariwisata, serta financial technology (Siregar 2016). Jika dibandingkan dengan tahun 2014 yang hanya mencapai 83,7 juta tingkat pengguna teknologi finansial, dalam hal ini akses internet di Indonesia, telah menunjukkan peningkatan yang signifikan dan dapat dicermati secara detail pada tabel 1 berikut ini (Julianto 2016): 
Tabel 1

Daftar 25 Negara Peringkat Teratas Pengguna Internet 2013-2018

(dalam jutaan jiwa)

\begin{tabular}{|c|c|c|c|c|c|c|c|}
\hline No. & Negara & 2013 & 2014 & 2015 & 2016 & 2017 & 2018 \\
\hline 1. & China & 620,7 & 643,6 & 669,8 & 700,1 & 736,2 & 777,0 \\
\hline 2. & Amerika Serikat & 246,0 & 252,9 & 259,3 & 264,9 & 269,7 & 274,1 \\
\hline 3. & India & 167,2 & 215,6 & 252,3 & 283,8 & 313,8 & 346,3 \\
\hline 4. & Brazil & 99,2 & 107,7 & 113,7 & 119,8 & 123,3 & 125,9 \\
\hline 5. & Jepang & 100,0 & 102,1 & 103,6 & 104,5 & 105,0 & 105,4 \\
\hline 6. & Indonesia & 72,8 & 83,7 & 93,4 & 102,8 & 112,6 & 123,0 \\
\hline 7. & Rusia & 77,5 & 82,9 & 87,3 & 91,4 & 94,3 & 96,6 \\
\hline 8. & Jerman & 59,5 & 61,6 & 62,2 & 62,5 & 62,7 & 62,7 \\
\hline 9. & Meksiko & 53,1 & 59,4 & 65,1 & 70,7 & 75,7 & 80,4 \\
\hline 10. & Nigeria & 51,8 & 57,7 & 63,2 & 69,1 & 76,2 & 84,3 \\
\hline 11. & Inggris & 48,8 & 50,1 & 51,3 & 52,4 & 53,4 & 54,3 \\
\hline 12. & Perancis & 48,8 & 49,7 & 50,5 & 51,2 & 51,9 & 52,5 \\
\hline 13 & Filipina & 42,3 & 48,0 & 53,7 & 59,1 & 64,5 & 69,3 \\
\hline 14. & Turki & 36,6 & 41,0 & 44,7 & 47,7 & 50,7 & 53,5 \\
\hline 15. & Vietnam & 36,6 & 40,5 & 44,4 & 48,2 & 52,1 & 55,8 \\
\hline 16. & Korea Selatan & 40,1 & 40,4 & 40,6 & 40,7 & 40,9 & 41,0 \\
\hline 17. & Mesir & 34,1 & 36,0 & 38,3 & 40,9 & 43,9 & 47,4 \\
\hline 18. & Italia & 34,5 & 35,8 & 36,2 & 37,2 & 37,5 & 37,7 \\
\hline 19. & Spanyol & 30,5 & 31,6 & 32,3 & 33,0 & 33,5 & 33,9 \\
\hline 20. & Kanada & 27,7 & 28,3 & 28,8 & 29,4 & 29,9 & 30,4 \\
\hline 21. & Argentina & 25,0 & 27,1 & 29,0 & 29,8 & 30,5 & 31,1 \\
\hline 22. & Kolombia & 24,2 & 26,5 & 28,6 & 29,4 & 30,5 & 31,3 \\
\hline 23. & Thailand & 22,7 & 24,3 & 26,0 & 27,6 & 29,1 & 30,6 \\
\hline 24. & Polandia & 22,6 & 22,9 & 23,3 & 23,7 & 24,0 & 24,3 \\
\hline 25. & Afrika Selatan & 20,1 & 22,7 & 25,0 & 27,2 & 29,2 & 30,9 \\
\hline \multicolumn{2}{|c|}{ Total Pengguna } & $2.692,9$ & $2.892,7$ & $3.072,6$ & $3.246,3$ & $3.419,9$ & $3.600,2$ \\
\hline
\end{tabular}

Sumber: $\underline{\text { www.eMarketer.com dalam Julianto (2016) }}$

Bertolak dari informasi yang telah diuraikan di atas, meskipun pengguna internet meningkat setiap tahunnya, namun pemanfaatan teknologi finansial untuk akses ke layanan perbankan di Indonesia masih relatif rendah. Menurut survei yang dilakukan oleh Sharing Vision pada 6 bank besar di Indonesia, jumlah pengguna internet banking mencapai 5,7 juta orang pada 2012. Jika dicermati pada Tabel 2 terlihat jelas bahwa dari tahun ke tahun jumlah pengguna internet semakin bertambah, namun jika dibandingkan dengan jumlah penduduk, nampak jelas bahwa persentase jumlah penduduk Indonesia yang menggunakan internet untuk akses layanan perbankan masih relatif rendah (Tim Penulis MRI 2016).

Tabel 2

Pengguna Internet di Indonesia Berdasarkan Opini Nasabah 6 Bank Tahun 2012-2015

\begin{tabular}{llll}
\hline Tahun & Jumlah Penduduk & Jumlah Pengguna Internet & Penetrasi Pengguna Internet \\
\hline 2012 & 240.000 .000 & $22 \%$ & $26 \%$ \\
2013 & 245.000 .000 & $30 \%$ & $34 \%$ \\
2014 & 248.000 .000 & $37 \%$ & $44 \%$ \\
2015 & 250.000 .000 & $42 \%$ & $56 \%$ \\
\hline
\end{tabular}

Sumber: Sharing Vision yang diolah dari berbagai sumber (2013) dalam MRI (2016). 
Selain faktor penggunaan teknologi finansial untuk akses ke lembaga perbankan yang masih relatif rendah, faktor lain yang menjadikan masyarakat Indonesia masih kesulitan dalam mengakses layanan perbankan, khususnya di daerah 3T (Terdepan, Terluar, dan Terpencil) adalah tidak meratanya akses terhadap layanan perbankan tersebut. Tidak meratanya akses terhadap layanan perbankan hingga kini masih menjadi permasalahan yang terus dihadapi oleh lembaga perbankan, khususnya masyarakat di daerah terpencil yang tidak dapat dijangkau oleh lembaga perbankan dan jasa keuangan tersebut, yang disebabkan oleh kondisi masyarakat yang belum sepenuhnya mengenal layanan perbankan dan jasa keuangan lainnya, sehingga berpotensi dimanfaatkan oleh pihak-pihak yang tidak bertanggung jawab (Habibi 2016).

Berdasarkan latar belakang yang telah diuraikan di atas, maka rumusan permasalahan yang diangkat adalah, "Bagaimanakah efektivitas implementasi teknologi finansial terhadap kualitas layanan perbankan di Indonesia apabila dianalisis berdasarkan kekuatan, kelemahan, peluang, dan ancaman (SWOT) agar mampu menjangkau seluruh lapisan masyarakat Indonesia, khususnya bagi masyarakat yang tinggal di daerah 3T (Terdepan, Terluar, dan Terpencil)? Dalam rangka menjawab perumusan masalah di atas, maka penelitian ini menggunakan kajian literatur keuangan dan perbankan. Dengan demikian, penelitian ini diharapkan dapat menjadi bahan rekomendasi bagi pihak manajemen perbankan untuk meningkatkan kualitas layanan terhadap nasabah atau pengguna jasa perbankan di seluruh wilayah Indonesia melalui implementasi teknologi finansial terkini.

\section{KAJIAN PUSTAKA DAN PERUMUSAN HIPOTESIS}

\section{Definisi Analisis SWOT}

Analisis SWOT adalah penilaian menyeluruh terhadap kekuatan (strengths), kelemahan (weaknesses), peluang (opportunities), dan ancaman (threats) suatu perusahaan (Kotler \& Armstrong 2008:64). Atau dengan kata lain, S-W-O-T digunakan untuk menilai kekuatan-kekuatan dan kelemahan-kelemahan dari sumbersumber daya yang dimiliki perusahaan dan kesempatan-kesempatan eksternal dan tantangan-tantangan yang dihadapi (Hartono 2005:46). Menurut (David 2006:8) semua organisasi memiliki kekuatan dan kelemahan dalam area fungsional bisnis, yang dapat digunakan sebagai dasar untuk tujuan dan penetapan strategi suatu organisasi. Jadi, analisis SWOT merupakan instrumen yang bermanfaat dalam melakukan analisis strategi, dalam konteks artikel ini ditujukan untuk menilai kualitas layanan perbankan, sehingga diharapakan mampu meminimalisasi kelemahan yang terdapat dalam suatu lembaga perbankan serta menekan dampak ancaman yang timbul dan harus dihadapi. 


\section{Teknologi Finansial Perbankan}

Mengacu pada data pengguna internet yang telah dijabarkan pada bagian pendahuluan, pemanfaatan teknologi digital dalam kehidupan masyarakat Indonesia sehari-hari ternyata telah mengubah perilaku masyarakat hampir pada semua aspek kehidupan, seperti jual beli secara online (e-commerce), interaksi sosial secara digital, buku elektronik, koran elektronik, transportasi publik (taksi dan ojek), layanan pendukung pariwisata, dan juga teknologi finansial (Siregar 2016). Data ini juga didukung oleh kajian kuantitatif yang menyatakan bahwa pemanfaatan teknologi informasi digital telah banyak membantu masyarakat Indonesia dalam menjalankan roda perekonomian menjadi lebih efektif dan efisien dari sebelumnya, khususnya pada sektor keuangan, khususnya perbankan (Margaretha 2015). Hal ini direspon positif oleh Bank Indonesia melalui penyediaan akses kemudahan dan ketersediaan layanan keuangan di seluruh wilayah Indonesia, di mana Bank Indonesia telah melakukan kajian awal dan uji coba branchless banking yang diluncurkan pada Mei 2013. Uji coba dimaksud dilakukan oleh 5 bank dan 2 telco pada 5 provinsi (Jawa Barat, Jawa Tengah, Jawa Timur, Bali, dan Sumatera Selatan). Tujuan dari uji coba dimaksudkan adalah untuk mencari apakah terdapat buying need dari masyarakat dan provider, bentuk model bisnis, dan pengaturan yang sesuai dengan kondisi Indonesia. Branchless banking ini terutama dilakukan dengan memanfaatkan tingginya penggunaan telepon genggam, serta kerjasama dengan unit lokal atau agen (Bank Indonesia 2016). Hal tersebut semakin memantapkan kinerja perbankan dalam memberikan layanan kepada nasabah melalui sistem informasi teknologi finansial. Senada dengan pendapat di atas, technology finansial dinilai menjadi faktor penting dalam mendorong inklusi keuangan dan perbankan digital Indonesia (Julianto 2016). Demikian halnya dengan Sutojo (1997:119) menyatakan bahwa teknologi electronic data processing, di mana sekarang dikembangkan menjadi teknologi finansial telah banyak membantu bank dalam kecepatan dan akurasi pemrosesan data operasi bisnis dan pemasaran produk mereka. Senada dengan pendapat di atas, penerapan sistem informasi sangat berpengaruh pada industri perbankan, di mana penerapan sistem informasi pada industri perbankan mempunyai dampak yang luar biasa mengingat industri perbankan merupakan salah satu industri yang paling tinggi tingkat ketergantungannya pada aktivitas-aktivitas pengumpulan, pemprosesan, analisa dan penyampaian laporan (informasi) yang diperlukan untuk memenuhi kebutuhan para nasabahnya (Kurnia et al., 2015).

Bertolak dari kajian konseptual di atas, saat ini perbankan Indonesia masih memiliki pengaruh yang paling besar dalam mendukung stabilitas sistem keuangan (Otoritas Jasa Keuangan 2016:5), sehingga implementasi teknologi finansial sangat diharapkan berperan aktif untuk menjangkau setiap elemen masyarakat, khususnya masyarakat di daerah 3T (Terdepan, Terluar, dan Terpencil) yang masih belum terakses kehadiran kantor cabang dari lembaga perbankan. hal ini didukung juga oleh OJK, yang saat ini tengah mengembangkan sistem teknologi finansial untuk 
digunakan dalam layanan di industri jasa keuangan, khususnya aplikasi layanan perbankan di Indonesia (Fajriah 2016).

\section{Kualitas Layanan Perbankan}

Ditinjau dari definisinya, maka kualitas merupakan suatu kondisi dinamis yang berpengaruh terhadap produk, jasa, manusia, proses dan lingkungan yang memenuhi atau melebihi harapan (Tjiptono 2001). Sedangkan definisi layanan menurut (Kotler 2002:83) yaitu setiap tindakan atau kegiatan yang dapat ditawarkan oleh suatu pihak kepada pihak lain, yang pada dasarnya tidak berwujud dan tidak mengakibatkan kepemilikan apapun. Sehingga jika kita berbicara mengenai kualitas layanan, maka istilah tersebut dapat didefinisikan sebagai upaya pemenuhan kebutuhan dan keinginan konsumen serta ketepatan penyampaiannya dalam mengimbangi harapan konsumen (Tjiptono 2001). Atau dengan pernyataan lain, pengertian kualitas layanan adalah sebuah kata yang bagi penyedia jasa merupakan sesuatu yang harus dikerjakan dengan baik (Supranto 2006:226).

Bertolak dari definisi tersebut, kajian mengenai kualitas layanan perbankan (banking service quality), dapat diketahui dengan cara membandingkan persepsi nasabah (customer) terhadap pelayanan yang mereka terima, disesuaikan dengan standar kualitas layanan perbankan yang dimaksud kepada nasabahnya. Hal ini berarti apabila layanan perbankan yang diterima atau yang dirasakan (perceived service) oleh nasabah sesuai dengan apa yang diharapkan, maka kualitas layanan tersebut dipersepsikan baik atau berkualitas tinggi. Sebaliknya, apabila tingkat layanan yang diterima oleh nasabah lebih rendah daripada yang diharapkan, maka kualitas layanan perbankan tersebut dapat dipersepsikan buruk atau berkualitas rendah. Dengan demikian, persepsi yang ditunjukkan oleh nasabah akan memengaruhi loyalitas mereka terhadap perbankan dan akan menyampaikan persepsinya tersebut kepada nasabah yang lain. Hal ini berarti persepsi yang ditunjukkan oleh nasabah akan memengaruhi loyalitas nasabah secara langsung (Nursiana 2015). Hal senada juga disampaikan oleh Tobing et al. (2016), bahwa nasabah yang loyal cenderung bersedia menceritakan pengalaman positifnya kepada orang lain.

Bertolak dari beragam pernyataan di atas, pengkajian terhadap kualitas layanan perbankan dapat dicermati berdasarkan dimensi kualitas layanan atau yang biasa disebut dengan istilah service quality. Adapun dimensi kualitas layanan yang dimaksud dapat dijelaskan sebagai berikut (Lupiyoadi 2001:148).

1. Tangibles, yaitu kemampuan suatu perusahaan dalam menunjukkan eksistensinya kepada pihak eksternal. Penampilan dan kemampuan sarana dan prasarana fisik perusahaan dan keadaan lingkungan sekitarnya adalah bukti nyata dari pelayanan yang diberikan oleh pemberi jasa, meliputi fasilitas fisik (gedung, gudang, dan lain sebagainya), perlengkapan dan peralatan yang dipergunakan (teknologi), serta penampilan pegawainya. 
2. Reliability, yaitu kemampuan perusahaan untuk memberikan pelayanan sesuai yang dijanjikan secara akurat dan terpercaya. Kinerja harus sesuai dengan harapan pelanggan yang berarti ketepatan waktu, pelayanan yang sama untuk semua pelanggan tanpa kesalahan, sikap yang simpatik, dan dengan akurasi yang tinggi.

3. Responsiveness, yaitu kemauan untuk membantu dan memberikan pelayanan yang cepat (responsif) dan tepat kepada pelanggan, dengan penyampaian informasi yang jelas.

4. Assurance, yaitu pengetahuan, kesopansantunan, dan kemampuan para pegawai perusahaan untuk menumbuhkan rasa percaya para pelanggan kepada perusahaan. Terdiri dari beberapa komponen antara lain komunikasi, kredibilitas, keamanan, kompetensi, dan sopan santun.

5. Emphaty, yaitu memberikan perhatian yang tulus dan bersifat individual atau pribadi yang diberikan kepada para pelanggan dengan berupaya memahami keinginan konsumen. Di mana suatu perusahaan diharapkan memiliki pengertian dan pengetahuan tentang pelanggan, memahami kebutuhan pelanggan secara spesifik, serta memiliki waktu untuk pengoperasian yang nyaman bagi pelanggan.

Berdasarkan kajian terhadap dimensi kualitas layanan di atas, maka dapat dikatakan bahwa kualitas layanan merupakan salah satu faktor utama yang selama ini memengaruhi kepuasan nasabah lembaga perbankan. Pemberian pelayanan yang terbaik kepada para nasabah oleh lembaga perbankan diperlukan untuk menjaga loyalitas nasabah dan kredibilitas bank.

\section{METODA PENELITIAN}

Metoda penelitian yang digunakan dalam penulisan artikel ini adalah deskriptif kualitatif. Adapun penelitian deskriptif kualitatif ditujukan untuk mengumpulkan informasi secara aktual dan terperinci, mengidentifikasi masalah, membuat perbandingan atau evaluasi, dan menentukan apa yang dilakukan orang lain dalam menghadapi masalah yang sama dan belajar dari pengalaman mereka untuk menetapkan rencana dan keputusan di waktu mendatang (Suyanto \& Sutinah 2006). Dengan demikian, penelitian deskriptif kualitatif hanyalah menguraikan tanggapan terhadap situasi atau peristiwa, sehingga tidak menjelaskan hubungan kausalitas maupun melakukan uji hipotesis. 


\section{ANALISIS DAN PEMBAHASAN}

\section{Analisis SWOT Implementasi Teknologi Finansial Terhadap Kualitas Layanan Perbankan}

Implementasi teknologi finansial dalam lembaga perbankan memberikan terobosan dalam layanan perbankan yang lebih cepat, mudah, dan aman sehingga seluruh elemen masyarakat Indonesia dapat menikmati akses terhadap layanan tersebut. Berikut ini akan dibahas secara detail mengenai kajian terhadap kekuatan (Strengths), kelemahan (Weaknesses), peluang (Opportunities), dan ancaman (Threats):

\section{Analisis Kekuatan (Strengths Analysis)}

Teknologi finansial yang akan diimplementasikan dalam lembaga perbankan di Indonesia memiliki analisis kekuatan sebagai berikut:

1. Kemudahan dalam memanfaatkan akses data layanan perbankan dalam ukuran besar dan kemudahan untuk melakukan transaksi kapan saja dan di mana saja.

2. Kemampuan untuk menjangkau kelompok masyarakat yang tidak terlayani oleh kantor cabang lembaga perbankan, khususnya di daerah 3T.

3. Lebih hemat biaya operasional dan biaya pemasaran karena lembaga perbankan cukup berkolaborasi dengan penyedia jasa teknologi finansial dalam menawarkan produk perbankan kepada masyarakat.

4. Varian produk lembaga perbankan yang telah banyak dikenal luas oleh masyarakat, termasuk aplikasi layanan 24 jam, seperti mobile banking, internet banking, sms banking, dan call banking (Rahadi \& Zanial 2015). Meskipun layanan perbankan ini belum banyak dimaksimalkan penggunaannya, namun ketika lembaga perbankan berkolaborasi dengan penyedia jasa teknologi finansial, maka masyarakat akan semakin mudah mengakses produk layanan perbankan yang dimaksud.

\section{Analisis Kelemahan (Weaknesses Analysis)}

Teknologi finansial yang akan diimplementasikan dalam lembaga perbankan di Indonesia memiliki analisis kelemahan sebagai berikut: Pertama, membutuhkan koneksi internet yang mendukung, baik dari segi kecepatan akses maupun server yang stabil dalam mengirimkan file data, karena transaksi finansial akan berlangsung dengan lancar ketika akses internet tidak mengalami gangguan. Kedua, timbulnya aksi kejahatan online seperti penyadapan, pembobolan, dan cybercrime dalam transaksi finansial perbankan, membuat masyarakat menjadi ragu untuk melakukan transaksi online, sehingga membuat mereka tetap berharap adanya kantor cabang lembaga perbankan hadir di daerah mereka. Ketiga, tidak semua penyedia jasa layanan teknologi finansial yang memiliki lisensi untuk menjalin kerjasama dengan 
lembaga perbankan atau melakukan transaksi finansial secara tersistem dan legal, sehingga dimungkinkan terjadinya praktik penyalahgunaan wewenang atau penyimpangan transaksional, yang justru akan merugikan lembaga perbankan itu sendiri. Keempat, pengetahuan masyarakat akan teknologi finansial yang relatif rendah memungkinkan mereka tidak dapat maksimal dalam mengakses layanan perbankan, sehingga pemerintah, dalam hal ini OJK dan BI, berkolaborasi dengan lembaga perbankan dan penyedia jasa teknologi finansial perlu melakukan sosialisasi penggunaan teknologi finansial tersebut. Keima, ketimpangan akses layanan perbankan karena infrastruktur teknologi komunikasi yang tidak merata antara daerah perkotaan dengan daerah 3T, menyebabkan masyarakat kesulitan melakukan transaksi finansial secara online, sehingga layanan perbankan tidak dapat dirasakan secara maksimal.

\section{Analisis Peluang (Opportunities Analysis)}

Teknologi finansial yang akan diimplementasikan dalam lembaga perbankan di Indonesia memiliki analisis peluang sebagai berikut: Pertama, kesadaran masyarakat yang mulai tumbuh untuk menyimpan dan meminjam kebutuhan finansial melalui jasa perbankan, karena dianggap lebih aman dan menguntungkan dengan harapan tingkat penerimaan bunga yang tinggi ketika menyimpan dana maupun biaya bunga yang relatif terjangkau ketika melakukan transaksi peminjaman dana perbankan. Kedua, adanya Otoritas Jasa Keuangan (OJK) yang menetapkan regulasi dan pengawasan terhadap transaksi finansial perbankan, sehingga meminimalisasi tindak kriminalitas perbankan dan kekuatiran masyarakat untuk menggunakan layanan teknologi finansial yang diselenggarakan oleh lembaga perbankan.

\section{Analisis Ancaman (Threats Analysis)}

Teknologi finansial yang akan diimplementasikan dalam lembaga perbankan di Indonesia memiliki analisis ancaman sebagai berikut: pertama, penggunaan teknologi yang semakin canggih oleh penyedia jasa teknologi finansial, namun tanpa disertai dengan peningkatan kualitas sumber daya manusia perbankan, menjadikan ketimpangan dalam melayani masyarakat pengguna layanan perbankan tersebut. Kedua, adanya trend globalisasi dan keterbukaan dalam melakukan transaksi lintas negara, memungkinkan penyedia jasa layanan teknologi finansial semakin beragam dan menimbulkan kompetisi dalam menarik minat masyarakat untuk menggunakan jasa layanan perbankan. Ketiga, situasi politik yang kurang kondusif dan kecenderungan terjadinya inflasi yang relatif tinggi di Indonesia, menyebabkan lembaga perbankan harus lebih berhati-hati dalam menyalurkan pinjaman kepada masyarakat, sehingga akan berdampak pada rumitnya birokrasi perbankan dan biaya administrasi yang dibebankan kepada masyarakat sebagai jaminan semakin tinggi. 


\section{SIMPULAN, KETERBATASAN DAN SARAN}

\section{Simpulan}

Setelah melakukan analisis kekuatan, kelemahan, peluang, dan ancaman (SWOT) terhadap implementasi teknologi finansial, maka dapat disimpulkan bahwa teknologi finansial tersebut memiliki tingkat efektivitas yang baik untuk meningkatkan kualitas layanan perbankan di Indonesia, sehingga pihak manajemen perbankan dapat mengimplementasikannya untuk menjangkau seluruh lapisan masyarakat Indonesia, khususnya bagi masyarakat yang tinggal di daerah 3T (Terdepan, Terluar, dan Terpencil).

\section{Keterbatasan dan Saran}

Teknologi finansial memiliki tingkat efektivitas yang baik untuk meningkatkan kualitas layanan perbankan di Indonesia, namun implementasi teknologi finansial di Indonesia masih tergolong baru dan kajian literasi yang relevan dengan teknologi finansial tersebut masih sangat terbatas. Untuk itu perlu upaya tindak lanjut dari pemerintah, OJK, praktisi perbankan, serta penyedia jasa teknologi finansial untuk melakukan kajian yang lebih mendalam secara berkelanjutan terhadap implementasi teknologi finansial tersebut di Indonesia. Dengan demikian, lembaga perbankan dan penyedia jasa teknologi finansial perlu melakukan kolaborasi yang matang dan terstruktur dengan pemerintah, dalam hal ini BI dan OJK. Kolaborasi tersebut bertujuan agar kelemahan dan ancaman terhadap transaksi finansial perbankan dapat diminimalisasi, sehingga setiap elemen masyarakat dapat mengakses setiap fitur maupun produk perbankan yang ditawarkan oleh lembaga perbankan di Indonesia secara cepat, aman, dan bermanfaat untuk pemenuhan kebutuhan finansialnya.

\section{DAFTAR PUSTAKA}

Apriyani. 2016. "OJK: waspadai dampak teknologi perbankan." Infobanknews. 2016.

Bank_Indonesia. 2016. “Layanan keuangan digital.” 2016.

David, Fred R. 2006. Manajemen strategis. Edisi ke S. Jakarta: Penerbit Salemba Empat.

Fajriah, L. 2016. "OJK, BI dan kemenkeu siapkan aturan soal sistem fintech." Sindonews. 2016.

Firmansyah, dan Widiati. 2016. "Maksimalisasi nilai perbankan syariah melalui teknologi pelayanan nasabah terkini." Jurnal Keuangan dan Perbankan 20 (2): 274-81.

Habibi, Y. 2016. "Refleksi setahun laku pandai.” Republika. 2016. 
Hartono, Jogiyanto. 2005. Sistem informasi strategik untuk keunggulan kompetitif. Yogyakarta: Penerbit Andi Offset.

Heriyanto, T. 2015. "Pengguna internet Indonesia capai 88,1 juta." CNN Indonesia. 2015.

Julianto, P.A. 2016. “Cara perbankan penuhi kebutuhan nasabah.” Kompas. 2016.

Kotler, Philip. 2002. Manajemen pemasaran di indonesia: analisis, perencanaan, implementasi dan pengendalian. Jakarta: Penerbit Salemba Empat.

Kotler, Philip, dan Gary Armstrong. 2008. Prinsip-prinsip pemasaran jilid 1. Jakarta: Penerbit Erlangga.

Kurnia, Supriyadi, dan Masjono. 2015. "Pengaruh hubungan pemanfaatan aplikasi core banking system terhadap kinerja individu karyawan PT. Bank BRI Syariah.” Jurnal Akuntansi, Keuangan dan Perbankan (Account) 1 (3): 24754.

Lupiyoadi, Rambat. 2001. Manajemen pemasaran jasa. Edisi ke S. Jakarta: Penerbit Salemba Empat.

Margaretha, F. 2015. "Dampak electronic banking terhadap kinerja perbankan Indonesia.” Jurnal Keuangan dan Perbankan 19 (3): 514-24.

MRI. 2016. “Prospek bisnis e-banking.” Buletin MRI. 2016.

Nursiana, A. 2015. "Pengaruh internet banking, kualitas layanan, reputasi produk, lokasi, terhadap loyalitas nasabah dengan intermediasi kepuasan nasabah." Jurnal Keuangan dan Perbankan 19 (3): 450-62.

Otoritas_Jasa_Keuangan. 2016. Perbankan: Seri literasi keuangan perguruan tinggi. Jakarta: Penerbit OJK.

Rahadi, dan Zanial. 2015. "Analisis technology acceptance model pada industri perbankan.” Jurnal Sistem Informasi (JSI) 7 (2): 837-51.

Siregar, A. 2016. "Financial technology tren bisnis keuangan ke depan." Infobanknews. 2016.

Sukma, D. 2016. "Fintechfest, mempopulerkan teknologi finansial di Indonesia." Arena LTE. 2016.

Supranto, J. 2006. Pengukuran tingkat kepuasan pelanggan. Cetakan ke tiga. Jakarta: Penerbit Rineka Cipta.

Sutojo, Siswanto. 1997. Manajemen terapan bank. Jakarta: Pustaka Binaman Pressindo.

Suyanto, Bagong, dan Sutinah. 2006. Metode penelitian sosial. Jakarta: PT Kencana Persada.

Tjiptono, Fandy. 2001. Strategi pemasaran. Edisi ke S. Yogyakarta: Penerbit Andi 
Offset.

Tobing, Fathorazzi, dan Wulandari. 2016. "Model inovasi sistem pemasaran perbankan syariah berbasis floating market untuk penciptaan daya saing (model of islamic banking marketing innovation systems based on floating market for creation competitiveness)." Jurnal Keuangan dan Perbankan 20 (1): 75-83. 